\title{
AEROMAGNETIC MAP OF PART OF THE SCITUATE QUADRANGLE, PLYMOUTH COUNTY, MASSACHUSETTS
}

\author{
GEOPHYSICAL INVESTIGATIONS \\ MAP GP-767
}

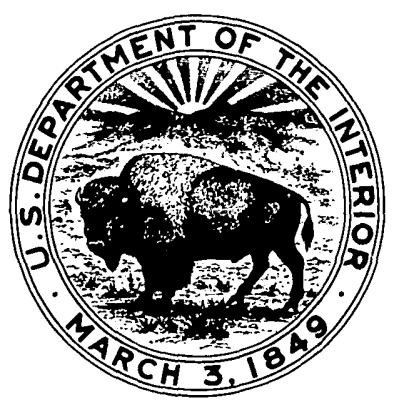

